only a little stiff, as in all cases of application of a plasterof-Paris bandage around a joint. Active and passive movements of the knee were now performed, and the woman and her family instructed in the process.

Four months after the definitive dismissal, the woman returned at my request. The movements, active and passive, in the knee-joint were now made with the same force and over the same extent as in the left knee-joint. By the most careful examination I could not find a groove between the two bone fragments, but rather a little crista (superfluous bone formation), nor could I detect the platina wire. Even on pressure there was no spot of tenderness by which foreign bodies often indicate their presence in the tissues.

During the operation I found the bottom of the interstice between the two fragments of the patella closed by a membrane, that adhered to the posterior surface of the bone fragments, which membrane separated the cavity between the two fragments from the cavity of the knee-joint, and thus prevented the more or less irritating carbolic solution from penetrating the joint. The adhesion of this membrane to the posterior surface of the patella was so firm that it was not broken by the necessary manipulations during the boring of the canals. That this membrane was not the plica synovialis patellaris (Henle)-ligamentum marsupiale, alare s. ligamenta alaria-I supposed; and by experiments in cadavere (transfixing that plica by strong needles pushed through the patella in the extended knee-joint), I found that this plica does not reach as high as the middle of the patella. By this experiment I found the explanation-that part of the synovial membrane that covers the anterior surface of the femur, that forms the posterior wall of the recessus sub quadricipe, is, namely, very feebly connected by very loose connective tissue to the bone, so that it is moderately movable. During straight extension of the knee-joint, the posterior surface of the patella rests on that part of the synovial membrane, and can, as in our case, adhere to it by a light adhesive inflammation, and thereby separate the groove between the patella fragments from the cavity of the joint. This is of great importance, as thereby the metallic suture of the broken patella can be performed without making a perforating wound of the joint. It is therefore that I recommend waiting about eight days after the accident before performing the metallic suture of the transverse broken patella, and that it should not be done save under the most rigid antiseptic precautions.

$$
\text { I am, Sir, vours, \&c, }
$$

Dr. J. E. VAN DER MEULEN, Lecturer on Operative Surgery at the University

Dec. 16th, 1879 of Utrecht.

\section{BADER v. GORDON.}

To the Editor of THE LANCET.

SIR,-Like Mr. Critchett, I must for a moment forget the good proverb, "qui s'excuse s'accuse." Mr. Critchett was subpœnaed, and he obeyed the law and appeared. This has repeatedly happened to me, but never to give evidence against one of my own profession. Often I escaped the subpcena by stating that my medical evidence would go against those who demanded my assistance. In Mr. Gordon's medical evidence it is said that I might have wounded the crystalline lens, and caused cataract (since Mr. Gordon had cataract, this would not have signified, though the suggestion, to say the least, was an ungenerous one). This, however, falls to the ground by the fact that Mr. Gordon had it explained to him that two operations would be required for the absorption of cataract. Injury to the iris and crystalline lens is, as a rule, followed by pain and inflammation. Mr. Gordon, after the iridectomy, had not the least pain nor unfavourable symptoms. His medical advisers might have stated this fact in my favour, but did not even hint at the smooth course which the case took after the iridectomy.

Cautious answers were given to Mr. Gordon by Mr. Bowman, and $\mathrm{Mr}$. Bowman distinctly stated in court that Mr. Gordon had not lost binocular vision. Mr. Gordon, however, laid much stress upon his loss of binocular vision. Surely Mr. Critchett knows that good convergence, parallel movements, perception of light and colours with both eyes, are also essentials of binocular vision. Mr. Gordon, by virtue of his cataract, had lost binocular power of reading, but not the other attributes of binocular vision ; and just because he possessed the latter, the treatment of the cataract was advised.

Mr. Critchett, in his note in The LANCET of Dec. 20th, states, "the fundus was so far examined that a detachment of the retina," \&c.; a little further on, " surely the ophthalmoscopic examination could only have been made," \&c.

It is most tedious to have to repeat the A B C of an ophthalmoscopic examination for displaced retina when there is a cataract-i.e., when one is prevented from seeing. the fundus of the eye.

Mr. Soelberg Wells, the energetic and able oculist, years ago made known the method (a translation of Von Graefe's articles) in the reports of the Eye Infirmary, Moorfields.

To the oculist of even moderate experience is known the frequent complication of displaced retina with cataract in short-sighted persons. This is one of the drawbacks of these cases, hence the note in my case-book, "displaced retina." When I found Mr. Gordon had only perception of light and could not see to read, I was anxious to ascertain with the ophthalmoscope the degree of perception of light of the different parts of the retina, and having at a second interview with Mr. Gordon found that satisfactory, I entered the note in my case-book " normal perception of light all over ;" that means in all parts of the retina (light of different intensity is, with the ophthalmoscope, thrown from different sides through the cataract into the eye, and if especially the lower parts of the retina perceive it well, the doubt as to displaced retina is removed, though the retina cannot be seen).

Surely Mr. Critchett knew all this ; if not, let him own it, instead of exposing himself to the suspicion of ill-will towards a fellow oculist.

I am, Sir, yours, \&c.,

$$
\text { C. BADER, }
$$

Dec. 23rd, $1879 . \quad$ Ophthalmic Surgeon to Guy's Hospital.

\section{THE ARMY MEDICAL SERVICE.}

\section{To the Editor of THE LANCET.}

SIR,-Having many personal friends amongst the medical officers of the Brigade of Guards, I beg to echo the remarks of your correspondent, "Army Surgeon," in your issue of the 20th December, respecting the unfairness which has been dealt out to them by the recent Royal Warrant, which not only practically refuses promotion to the Surgeon and reduces his pay, but also totally ignores the claims of the Surgeons-Major to be promoted to the new rank of BrigadeSurgeon, by insisting upon an amount of foreign service which it is not possible for these officers to attain whilst the present custom prevails of only sending the guards abroad during great wars.

The Regimental Surgeons-Major of the Foot Guards have from time immemorial discharged duties precisely the same as those now proposed for Brigade Surgeons, and, in addition, acted as Principal Medical Officers of their regiments.

The Surgeon-Major of the Grenadier Guards is P.M.O of three battalions, with six medical officers serving under him; whilst those of the Coldstream and Scots Guards have similar duties, with two battalions and five medical officers each.

In addition to regimental duties, the Surgeon-Major in Brigade Waiting has to be at the call of the Major-General Commanding, to advise him upon all departmental matters connected with the Brigade of Guards, thus discharging administrative functions little short of those of a Deputy Surgeon-General, whilst his pay is only that of an ordinary Surgeon-Major in the army.

Notwithstanding all this, he is declared to be unfit for promotion to Brigade Surgeon because he has not sufficient foreign service, although he has served with his regiment in the Crimea, at Alma, Inkerman, and Sebastopol, and would have volunteered to serve in smaller wars had he been permitted to do so.

The duties of the juniors are not limited to their own regiments, and, in consequence of numerous detachments, are heavier than those of other army surgeons on home service, as they often have to travel long distances without receiving any allowance for forage or cab hire; whilst they labour under the great disadvantages respecting pay and promotion pointed out by your correspondent above alluded to.

The Guards' Surgeon is usually "a picked man," profes- 